\title{
Impacts of Detailed Land-Use Types and Urban Heat in an Urban Canopy Model on Local Meteorology and Ozone Levels for Air Quality Modeling in a Coastal City, Korea
}

\author{
Yoon-Hee Kang ${ }^{1}$, Sang-Keun Song ${ }^{2}$, Mi-Kyeong Hwang ${ }^{3}$, Ju-Hee Jeong ${ }^{3}$, and Yoo-Keun Kim ${ }^{3, *}$ \\ ${ }^{I}$ The Institute of Environmental Studies, Pusan National University, Busan, Republic of Korea \\ ${ }^{2}$ Department of Earth and Marine Sciences, Jeju National University, Jeju, Republic of Korea \\ ${ }^{3}$ Department of Atmospheric Sciences, Pusan National University, Busan, Republic of Korea
}

Received 25 August 2015, revised 12 January 2016, accepted 13 January 2016

\begin{abstract}
An urban canopy model (UCM), with detailed urban land-use and anthropogenic heat information, is required to reproduce and understand the urbanization process and its impact on regional climate and urban air quality. This study investigates the UCM impact on simulated meteorology and surface ozone in the coastal city of Busan using the WRF-SMOKE-CMAQ model coupled with (UCM case), and without the UCM (NOUCM case). The UCM and NOUCM case results suggest that UCM case generally produces warmer temperatures and deeper planetary boundary layer (PBL) heights, especially in the early morning and night time, than the NOUCM case. Owing to urban heating and enhanced turbulent mixing incorporation in the center of the city, the sea breeze in the UCM case tends to penetrate faster and more strongly than in the NOUCM case. After sea breeze arrival at the urban center, the urban heat island effect prevents its penetration further inland. In the UCM case in the late afternoon, local meteorological changes induce remarkable increases in simulated $\mathrm{O}_{3}$ concentrations over the downwind (up to $17.1 \mathrm{ppb}$ ) and downtown (up to $10.6 \mathrm{ppb}$ ) areas. This is probably due to an increase in temperature in the urban areas and the wind convergence zone movement due to the sea breeze interaction and offshore flows. The increase in $\mathrm{O}_{3}$ concentration in the late afternoon results in the model bias reduction under previously underestimated $\mathrm{O}_{3}$ conditions due to high NOx emissions. The simulated $\mathrm{O}_{3}$ concentrations in the UCM case are more similar to the observed $\mathrm{O}_{3}$ concentrations compared to those of the NOUCM case.
\end{abstract}

Key words: Urban canopy model, Air quality model, Surface ozone, Sea breeze, Coastal city

Citation: Kang, Y. H., S. K. Song, M. K. Hwang, J. H. Jeong, and Y. K. Kim, 2016: Impacts of detailed land-use types and urban heat in an urban canopy model on local meteorology and ozone levels for air quality modeling in a coastal city, Korea. Terr. Atmos. Ocean. Sci., 27, 877-891, doi: 10.3319/ TAO.2016.01.13.01(A)

\section{INTRODUCTION}

Urbanization results in a change in both regional climate and urban air quality (Wang et al. 2007; Heald and Spracklen 2015; Shi et al. 2015). Land-use changes, urban heat island (UHI), and anthropogenic heat from human activities in cities modify the thermal characteristics of the planetary boundary layer (PBL), alter regional climate and affect the transport and dispersion of air pollutants (Wang et al. 2009; Liao et al. 2015). In urbanized coastal cities, complex atmospheric circulations result from the interactions between the UHI effect and sea breezes. Several studies

\footnotetext{
* Corresponding author

E-mail:kimyk@pusan.ac.kr
}

have suggested that the UHI influences the intensity, speed of propagation and onset time of the sea breeze (Ado 1992; Yoshikado 1994). The UHI effect can strengthen or weaken the sea breeze according to size of the urban area and its distance from the coast, while the sea breeze itself can also modify the UHI pattern (Freitas et al. 2007). These modified local circulations have an effect on air pollutant horizontal and vertical distributions and can occasionally lead to severe air pollution in urban areas.

In order to understand the interaction between urbanization, meteorology and air quality in a coastal city, it is necessary to conduct the meteorological and air quality model coupled with an Urban Canopy Model (UCM). However, only few studies have considered the meteorological and air 
quality modeling with a UCM. Yu et al. (2012) demonstrated that urbanization produces higher ozone values with a maximum of more than $20 \mathrm{ppb}$ in Beijing-Tianjin-Hebei, and 14 ppb in the Yangtze River Delta, using a Weather Research and Forecasting model with Chemistry (WRF/Chem) with a UCM. Kim et al. (2015) reported that the $\mathrm{PM}_{10}$ vertical dispersion over Greater Paris was improved by the incorporation of a UCM into meteorology (WRF) and chemistry-transport (Polair3D/Polyphemus) models. These studies have tended to focus on the urban-rural temperature gradient impact on air quality and do not pay enough attention to the influence of urban characteristics on both local meteorology (e.g., sea and land breeze circulation) and air quality.

The main aim of this study is to assess the UCM impact, which considers detailed urban land types and urban heat, on predicted meteorological and $\mathrm{O}_{3}$ conditions during a high $\mathrm{O}_{3}$ episode at a coastal city. We run the Advanced WRF-Sparse Matrix Operator Kernel Emissions (SMOKE)Community Multiscale Air Quality (CMAQ) model both with and without the UCM and discuss the UCM impact on simulated local circulations, including the UHI, sea breeze and surface $\mathrm{O}_{3}$ concentrations. The physical and chemical processes associated with the simulated $\mathrm{O}_{3}$ concentrations are quantitatively determined using a process analysis within CMAQ.

\section{STUDY AREA, PERIOD, AND METHODS}

\subsection{Study Area}

Busan, which is the target area in this study, is the second largest metropolis in South Korea, located on the southeastern tip of the Korean Peninsula (Fig. 1a). It is one of the most densely populated cities in Korea, with a population of approximately 3.6 million (as of 2014) in an area covering $765.9 \mathrm{~km}^{2}$. The city is built upon a complex terrain with low and high mountains up to $750 \mathrm{~m}$ in altitude, in addition to a coastal area on its southeastern side facing the Korea Straits with an irregular coastline. Since the early 1990s, Busan has undergone rapid urbanization and industrialization, resulting in considerable urban expansion, including the construction
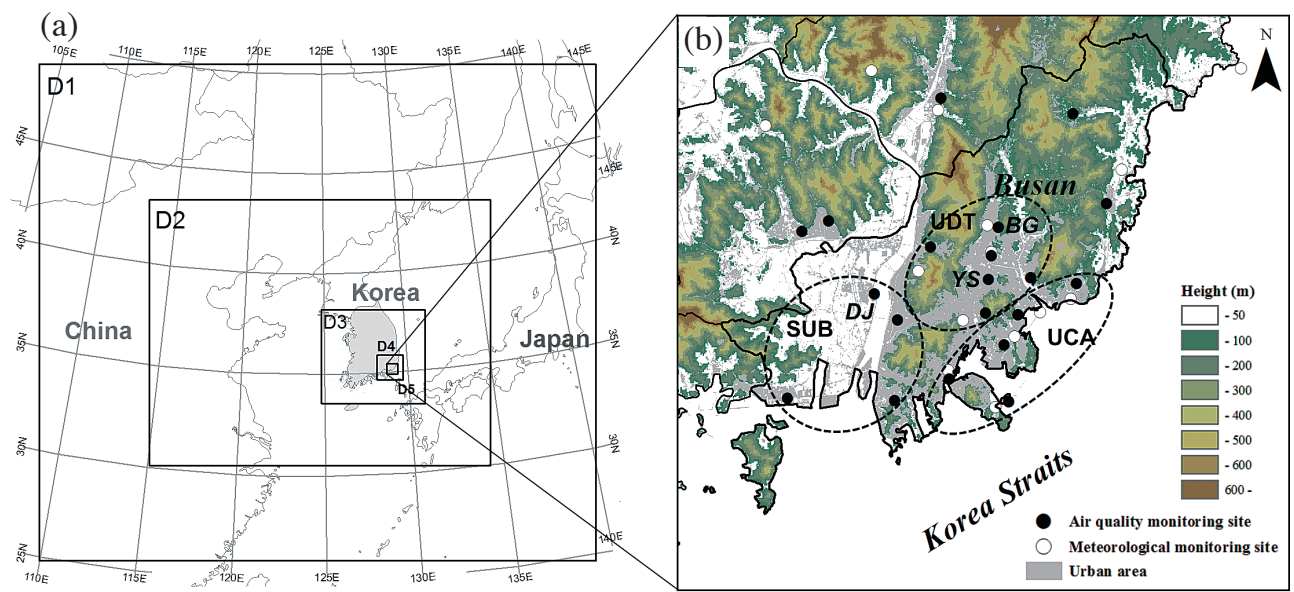

(c)

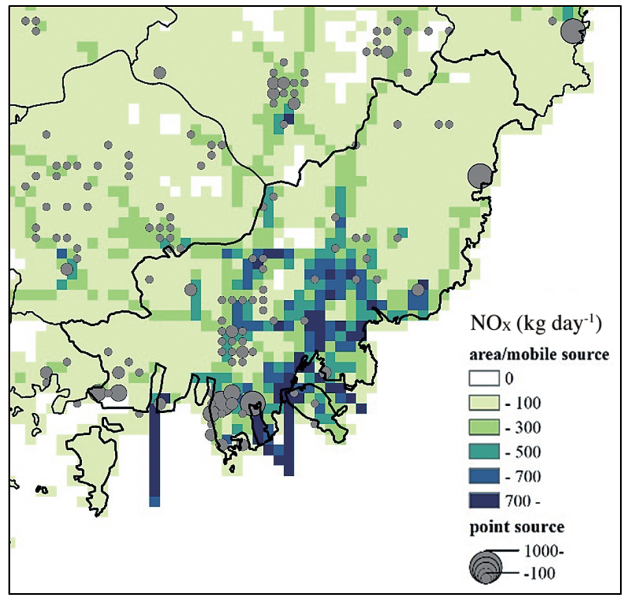

(d)

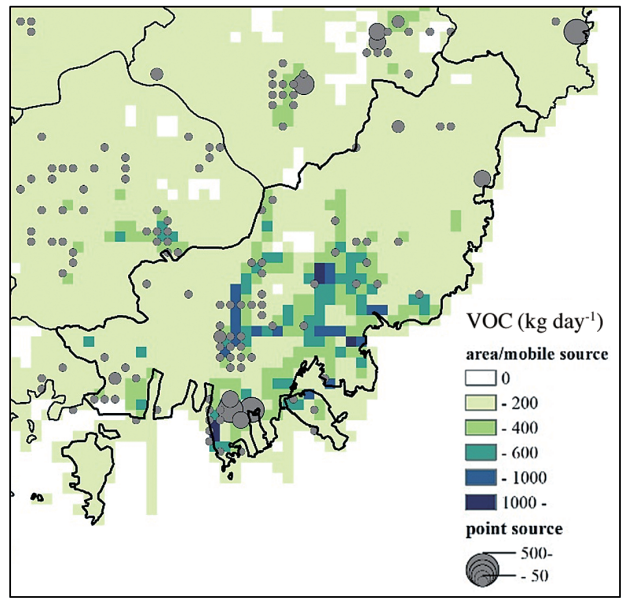

Fig. 1. Maps showing (a) the five nested grid domains (D1 - 5) for the WRF modeling; (b) a precise topography, urban area, meteorological, and air quality monitoring sites; (c) spatial distributions of $\mathrm{NO}_{x}$; and (d) $\mathrm{VOC}$ emissions $\left(\mathrm{kg} \mathrm{day}^{-1}\right)$ in the study domain. Air quality monitoring sites are indicated as: urban downtown area (UDT), urban coastal area (UCA), and suburban area (SUB). Bu Gok (BG) and Yeon San (YS) sites are located in UDT and Dae Jeo (DJ) site is located in SUB. (Color online only) 
of commercial buildings, roads, and ports, especially along the coastline. Based on Landsat Thematic Mapper (TM) data interpretation, the proportion of urban land use in this city has increased continuously over time, from $20.6 \%$ in 1985 to $24.2 \%$ in 2000 . This equates to around $1.8 \%$ year $^{-1}$ across the entire Busan area (Park and Baek 2009). Further, the urban land use could be seen to account for $25.6 \%$ of all Busan in 2003 (Fig. 1b), based on land-use data from the Environmental Geographical Information System (EGIS) (http://egis.me.go.kr/egis/).

Under rapid urbanization of the study area, a variety of gaseous pollutants (e.g., $\mathrm{NO}_{\mathrm{x}}$, VOC, and $\mathrm{CO}$ ) has been emitted predominantly as a result of human activities. The primary emission sources of these pollutants are on-road mobile sources (78731 ton $\mathrm{yr}^{-1}, 50.5 \%$ ), followed by non-road mobile sources such as shipping around port areas (27483 ton $\left.\mathrm{yr}^{-1}, 17.6 \%\right)$, and solvent utilization (27116 ton $\mathrm{yr}^{-1}, 17.4 \%$ ) [National Institute of Environmental Research (NIER) 2009]. The spatial distributions of area, mobile and point source emissions of $\mathrm{NO}_{\mathrm{x}}$ and VOC in the study area are shown in Figs. 1c and d, respectively. These emissions can be seen distributed mainly in the downtown and industrial areas, respectively. Additionally, vast $\mathrm{NO}_{x}$ emissions derived from shipping processes (1733 ton $\mathrm{yr}^{-1}$ ) are concentrated on the coast near Busan Port, and contribute significantly to changes in $\mathrm{O}_{3}$ concentrations in both the coastal and downwind regions (Song et al. 2010).

\subsection{Study Period (6 - 8 August 2006)}

Meteorological and air quality modeling was applied to the 6 - 8 August 2006, period which represent the most severe episodic $\mathrm{O}_{3}$ days in the last ten years. Table 1 provides a statistical summary of meteorological variables, including surface temperature, solar radiation, and cloud cover, as well as $\mathrm{O}_{3}$ concentrations during these episodic days. These data are based on hourly $\mathrm{O}_{3}$ concentrations and meteorological variables (air temperature, solar radiation, and cloud cover) observed at several air quality and meteorological monitoring sites (Fig. 1b) in the study area. On 7 and 8 August 2006, a daily maximum $\mathrm{O}_{3}$ concentration of $>120 \mathrm{ppb}$ was recorded, and $\mathrm{O}_{3}$ concentrations exceeding the national ambient air quality standard of $100 \mathrm{ppb} \mathrm{hr}^{-1}$ were observed at most of the air quality monitoring sites (10 and 9 sites on the two days, respectively). During the episodic period, very high daily maximum temperatures, equal to or greater than $30^{\circ} \mathrm{C}$, intense insolation and a clear sky, favorable for photochemical $\mathrm{O}_{3}$ production, were consistently observed.

Figure 2 shows the surface weather maps for 6 - $8 \mathrm{Au}$ gust 2006. The North Pacific High affected the Korean peninsula, resulting in stable and stagnant atmospheric conditions with high temperatures and limited vertical mixing. The local circulations, including land and sea breeze circulations, were well developed under these weak synoptic weather conditions. Under such favorable meteorological conditions, significant $\mathrm{O}_{3}$ production and accumulation episodes occur frequently (NRC 1991; Liu et al. 1994; Oh et al. 2006).

\subsection{Methods and Materials}

The surface energy budget and local winds are altered due to the UCM impact on the urban meteorological system. The $\mathrm{O}_{3}$ simulation was quantified through analysis of the differences between model-predicted values derived from two sets of simulation scenarios: (1) the WRF-SMOKECMAQ simulation coupled with the UCM, termed the UCM case; and (2) the same simulation without the UCM, termed the NOUCM case. To clarify the diurnal variation in differences between the UCM and NOUCM cases, the entire simulation period was divided into four periods in consideration of the typical diurnal variations in $\mathrm{O}_{3}$ concentrations: (1) the early morning after sunrise (06:00 - 10:00 LST); (2) around noon (11:00 - 15:00 LST); (3) the late afternoon until sunset (16:00 - 19:00 LST); and (4) at night (20:00 - 05:00 LST). Integrated processes rate (IPR) analysis was applied to quantify the UCM contribution to the physical and chemical processes relating to the predicted $\mathrm{O}_{3}$ concentrations. The IPR $\mathrm{O}_{3}$ concentration analysis includes examinations of the rates of gas-phase chemical production, horizontal transport, vertical transport, and dry deposition leading to net changes in $\mathrm{O}_{3}$ concentrations (Wang et al. 2010; Song et al. 2011; Kang et al. 2012). Busan was classified into three areas to assess the detailed contribution of the UCM under different urban and geographic conditions, such as urban or suburban, and coastal or inland areas: the urban coastal area (UCA), the urban downtown area (UDT), and suburban area (SUB), as shown in Fig. 1b. IPR analysis was applied to the 15 AQ monitoring sites belonging to each of the three classification areas.

In order to evaluate the agreement between observed

Table 1. Statistical summary of $\mathrm{O}_{3}$ and meteorological variables during the high $\mathrm{O}_{3}$ episodic days (6 - 8 August 2006).

\begin{tabular}{ccccccc}
\hline Date & $\begin{array}{c}\text { Averaged daily max. } \mathbf{O}_{3} \\
\text { concentration }(\mathbf{p p b})\end{array}$ & $\begin{array}{c}\text { Daily max. } \mathbf{O}_{3} \\
\text { concentration }(\mathbf{p p b})\end{array}$ & $\begin{array}{c}\text { The number of sites } \\
\text { exceeding standard level }\end{array}$ & $\begin{array}{c}\text { Daily max. } \\
\text { temperature }\left({ }^{\circ} \mathbf{C}\right)\end{array}$ & $\begin{array}{c}\text { Solar radiation } \\
\left(\mathbf{M J} \mathbf{~ m}^{-2}\right)\end{array}$ & $\begin{array}{c}\text { Daily mean Cloud } \\
\text { cover }(\%)\end{array}$ \\
\hline 6 August & $73.7 \pm 20.5$ & 108 & 1 & 33.2 & 26.47 & 1.25 \\
7 August & $111.2 \pm 39.4$ & 192 & 10 & 33.9 & 26.08 & 1.25 \\
8 August & $99.5 \pm 33.9$ & 183 & 9 & 34.5 & 27.30 & 0.88 \\
\hline
\end{tabular}


(a)

\section{August 2006}

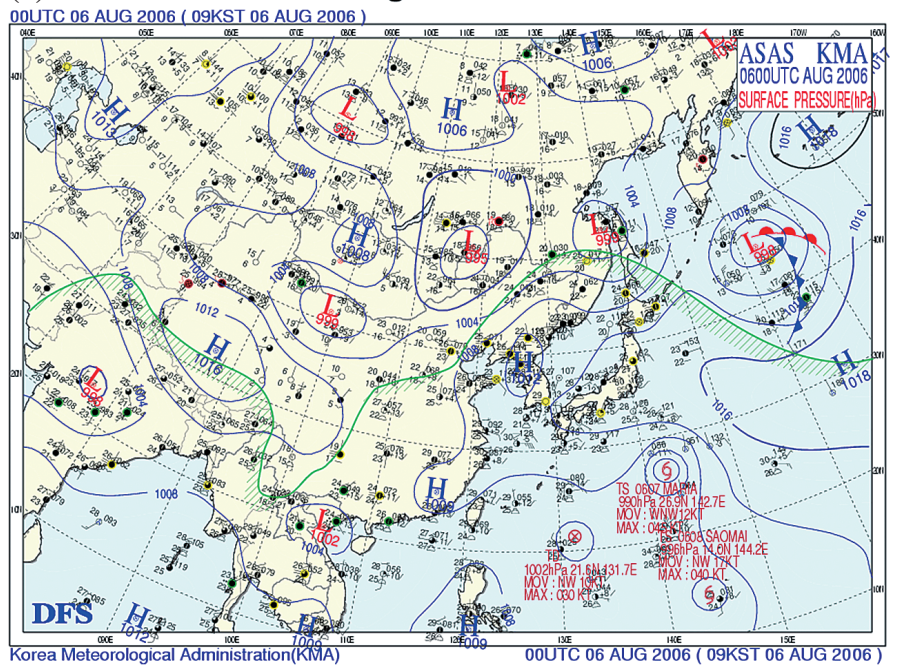

(b)

\section{August 2006}

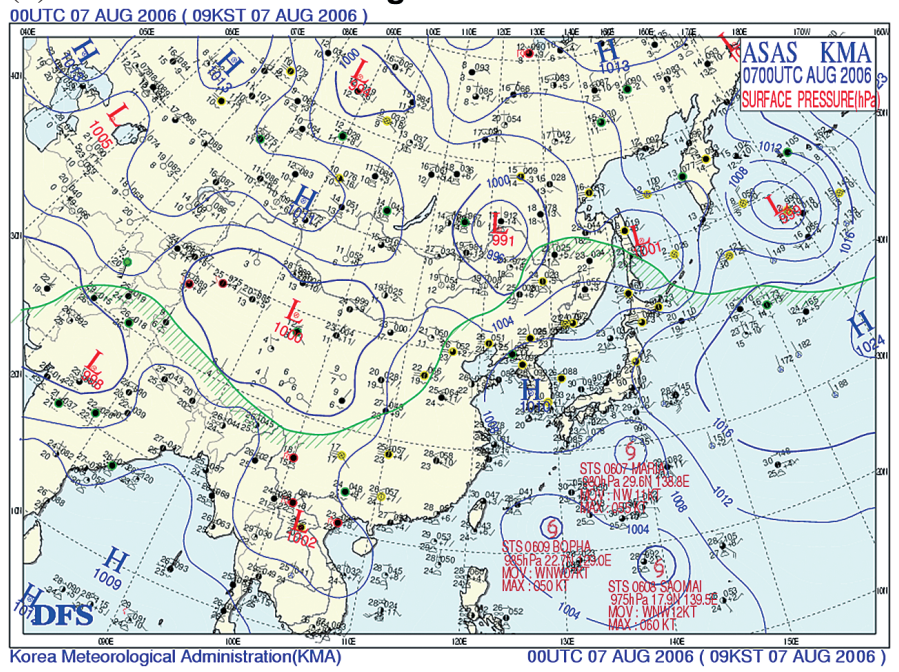

(c)

8 August 2006

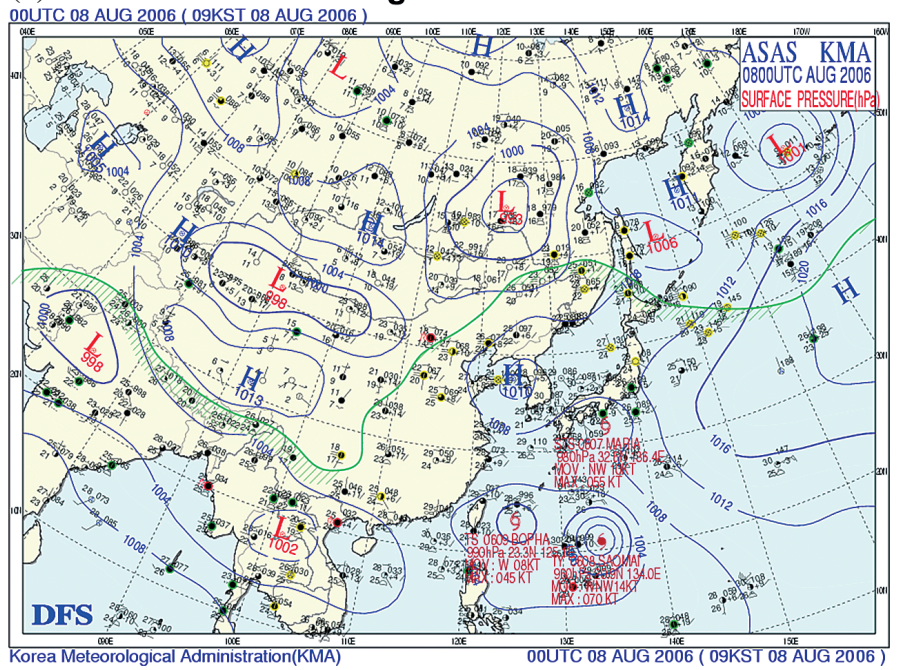

Fig. 2. The surface weather maps for (a) 6 August, (b) 7 August, and (c) 8 August 2006. (Color online only) 
and predicted meteorological variable values, including surface temperatures and wind speeds, and $\mathrm{O}_{3}$ concentrations, statistical performance was carried out for both the UCM and NOUCM cases at several monitoring sites (14 sites for the ME data and 20 sites for the AQ data) in the study domain across the entire simulation period (5 - 9 August 2006). Root Mean Square Error (RMSE), Mean Bias Error (MBE), and Mean Absolute Error (MAE) were used in this study as model accuracy measures (Emery et al. 2001).

\section{MODEL DESCRIPTIONS AND INPUT DATA}

\subsection{Meteorological Model}

The meteorological model used in this study is the WRF version 3.1, a non-hydrostatic model designed for numerical weather prediction on scales ranging from meters to thousands of kilometers, developed by the National Center for Atmospheric Research (Skamarock et al. 2008; Advanced Research WRF 2009). The computational domain in the WRF consists of 43 sigma vertical layers from the surface to $100 \mathrm{hPa}$ and five nested domains: downscaled from 81-km grids that cover Northeast Asia (D1, $48 \times 44$ array), 27-km grids (D2, $88 \times 76$ array), 9-km grids (D3, $79 \times 76$ array), 3 -km grids (D4, $70 \times 70$ array), and 1-km grids (D5, $61 \times$ 61 array) that include Busan and its surroundings, spanning $34.9-35.4^{\circ} \mathrm{N}$ and $128.7-129.4^{\circ} \mathrm{E}$ (Figs. $1 \mathrm{a}$ and b).

The initial/lateral boundary conditions were generated from the National Center for Environmental Prediction (NCEP) final analysis (FNL) data on $1.0 \times 1.0$ degree grids at every $6 \mathrm{~h}$ and the global sea surface temperature (SST) data on 0.5 degrees which was acquired daily. The following physical options were employed within the WRF simulations: the WRF Single-Moment 6-Class (WSM6) scheme for microphysics (Hong and Lim 2006); the Yonsei University (YSU) PBL scheme (Hong et al. 2006); the RRTM longwave radiation scheme (Mlawer et al. 1997), the Dudhia shortwave radiation schemes (Dudhia 1989); the Kain-Fritsch cumulus schemes (for only D1 and D2) (Kain 2004), and the Noah Land Surface Model (Noah LSM) (Chen and Dudhia 2001). The geographical data is used for D1 - D3 comprises the default downloadable data from the United States Geological Survey (USGS), including 25-category land use information. High resolution land use and topographic data were used for D4 and D5 obtained through the EGIS, from the Korean Ministry of Environment (KME), and the Shuttle Radar Topography Mission (SRTM) 3 s (http://www2.jpl. nasa.gov/srtm/) from the National Aeronautics and Space Administration (NASA), respectively. The WRF simulations were performed over a 168-h period beginning at 00:00 Universal Time Coordinated (UTC) 3 August to 00:00 UTC 10 August 2006 with an initial spin-up time of $24 \mathrm{~h}$.
Several meteorological variables under lower boundary conditions, including surface sensible and latent heat fluxes, and surface skin temperatures on roofs, walls, and roads, were simulated using a single-layer UCM to obtain a detailed estimation of the meteorological conditions in the complex urban environment. This UCM, when coupled with a WRF- Noah LSM, considers shadowing, reflections and radiation trapping in a street canyon (Tewari et al. 2007; Chen et al. 2011). In the UCM, the structures and characteristics of the urban area are basically parameterized using UCM variables, including building height, building coverage ratio and the heat capacity of roofs, roads and building walls, with reference to three urban categories: low intensity residential; high intensity residential; and commercial/ industrial/transportation. More detailed descriptions of the UCM are given in Kusaka et al. (2001) and Kusaka and Kimura (2004).

The UCM was only applied to the finest model domain (D5) in this study, covering Busan and its surroundings. The GIS data for the 3D building structures and classifications (e.g., residential, industrial, and commercial) in Busan were provided by the Ministry of Land, Transport and Maritime Affairs (MLTM) in Korea. Three urban categories for the UCM simulations were classified based on the respective properties corresponding to building area and classifications. For the residential building types, a dominant urban category for each urban grid is high intensity residential if the building area fraction within a grid is equal or greater than $30 \%$, otherwise it is low intensity residential. The urban canopy parameters for the urban categories are used from the default table distributed with WRF model. Figure 3 shows the dominant land use distribution and three urban categories in the study domain including the GIS building structure data. The urban areas are concentrated near the coast and in the center of the city, which is situated in a valley between mountains (Fig. 1b). The three urban categories, low intensity residential, high intensity residential, and commercial/ industrial/transportation, together comprise 51.6, 33.3, and $15.1 \%$ of the total urban area, respectively.

\subsection{Air Quality Model}

The air quality model is the CMAQ version 4.6 (http:// www.cmaq-model.org/), which is used to evaluate the spatio-temporal variability in the surface $\mathrm{O}_{3}$ concentrations on the studied episodic days (6 - 8 August 2006). The CMAQ developed by the U.S. Environment Protection Agency (EPA) is a 3D Eulerian photochemical model designed to understand the complex atmospheric chemistry and physics interactions (Byun and Ching 1999). The CMAQ domains comprise a coarse domain (3-km grids, $64 \times 64$ array) and a nested fine domain covering Busan city (1-km grids, $55 \times 55$ array). The model consists of 25 vertical layers from the surface to a height of $20 \mathrm{~km}$. The meteorological inputs 
for CMAQ were calculated from the WRF outputs, using the Meteorology-Chemistry Interface Processor (MCIP). For the chemical speciation process, the CB04 gas-phase chemistry mechanism was employed.

The initial and boundary conditions in the coarse domain were calculated from the default profile distributed with CMAQ by the U.S. EPA, but those for surface $\mathrm{NO}_{2}$, $\mathrm{SO}_{2}, \mathrm{CO}$, and $\mathrm{O}_{3}$ were derived from surface background data observed at the respective monitoring sites (total 16 sites) closest to the four coarse domain boundaries during August, 2006. SMOKE version 2.7 (http://www.smoke-model. org/version $2.7 / \mathrm{html} /$ index.html), developed by the MCNC Environmental Modeling Center (EMC), was used to prepare the hourly gridded emission inputs. The anthropogenic emission inventory in this study including area, mobile and point-source emissions, was developed using the 2007 Clean Air Policy Support System (CAPSS) by the NIER, Korea. Additionally, the biogenic emissions were estimated using the Biogenic Emission Inventory System (BEIS) v3.14 with the land-use data from EGIS and the vegetation data from Forest Information System (FGIS) provided by the Korea Forest Service (http://fgis.forest.go.kr/fgis/). The WRF-MCIP outputs were also used to vertically allocate major point sources and calculate the biogenic emissions for consideration alongside the meteorological conditions during the episodic days. The CMAQ modeling was conducted from 00:00 UTC on 4 August to 00:00 UTC on 10 August 2006 (6 days) with an initial spin-up period of $24 \mathrm{~h}$.

\section{RESULTS AND DISCUSSION}

\subsection{Difference Between UCM and NOUCM in Terms of Temperature, Wind Speed, and PBL Height}

Figure 4 shows the spatial distributions of the dif- ferences between UCM and NOUCM cases (UCM minus NOUCM) for averaged $2 \mathrm{~m}$ temperatures, PBL heights and $10 \mathrm{~m}$ wind speeds over the periods (06:00 - 10:00, 11:00 15:00, 16:00 - 19:00, and 20:00 - 05:00 LST) on 7 August 2006. The black line grids indicate the urban areas that were reclassified into the three UCM urban categories.

The $2 \mathrm{~m}$ temperatures across the entire domain in the UCM case were generally warmer, especially in the urban areas within the black line grids, than those of the NOUCM case, except for around noon (11:00 - 15:00 LST) (Fig. 4a). The spatial temperature averages were changed using the $\mathrm{UCM},+0.32^{\circ} \mathrm{C}\left(-0.32\right.$ to $\left.+2.07^{\circ} \mathrm{C}\right),+0.18^{\circ} \mathrm{C}$ $\left(-0.61\right.$ to $\left.+2.86^{\circ} \mathrm{C}\right)$, and $+0.46^{\circ} \mathrm{C}\left(-0.39\right.$ to $\left.+4.81^{\circ} \mathrm{C}\right)$ for the 06:00 - 10:00, 16:00 - 19:00, and 20:00 - 05:00 LST periods, respectively. In contrast, around noon when the air temperature reached its maximum $\left(33.9^{\circ} \mathrm{C}\right.$ at $14: 36 \mathrm{LST}$ on 7 August 2006), the difference between both simulations was small $\left(-0.03^{\circ} \mathrm{C}\right)$. The relatively large increases in the temperatures during the early morning and nighttime are likely caused by the UCM storing more incoming radiation and adding more anthropogenic heat during the daytime, which prevents rapid cooling after sunset. The surface temperatures are strongly associated with the changes in near-surface heat fluxes related to the urban environments, including anthropogenic heat release, urban surface characteristics, and building distribution (Zehnder 2002; Grossman-Clarke et al. 2005). The spatial net surface heat flux averages, representing the sum of the sensible heat flux, the latent heat flux and the ground heat flux, increase in the UCM case, by $17.3 \%$ $\left(25.1 \mathrm{~W} \mathrm{~m}^{-2}\right), 1.5 \%\left(6.8 \mathrm{~W} \mathrm{~m}^{-2}\right), 16.4 \%\left(28.8 \mathrm{~W} \mathrm{~m}^{-2}\right)$, and $89.6 \%\left(19.5 \mathrm{~W} \mathrm{~m}^{-2}\right)$ compared to the NOUCM case, for the 06:00 - 10:00, 11:00 - 15:00, 16:00 - 19:00, and 20:00 05:00 LST periods, respectively.

Figures $4 \mathrm{~b}$ and $\mathrm{c}$ indicate that the PBL heights and wind (a)

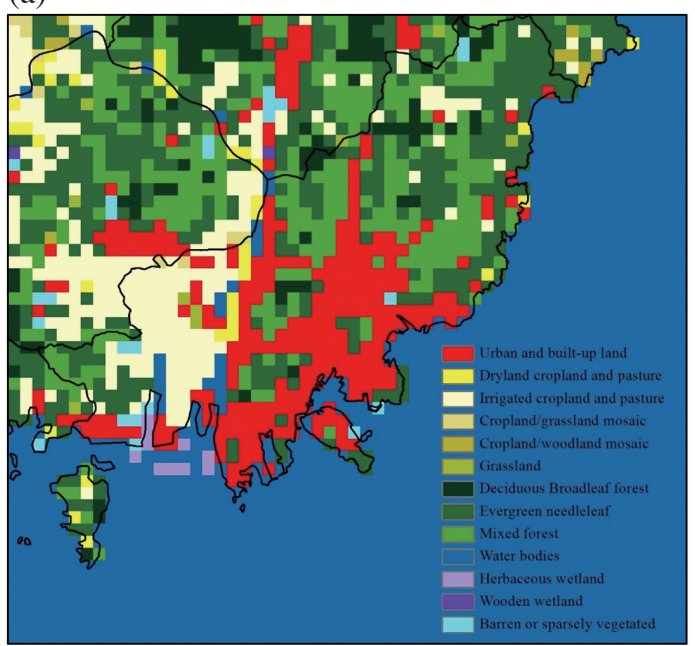

(b)

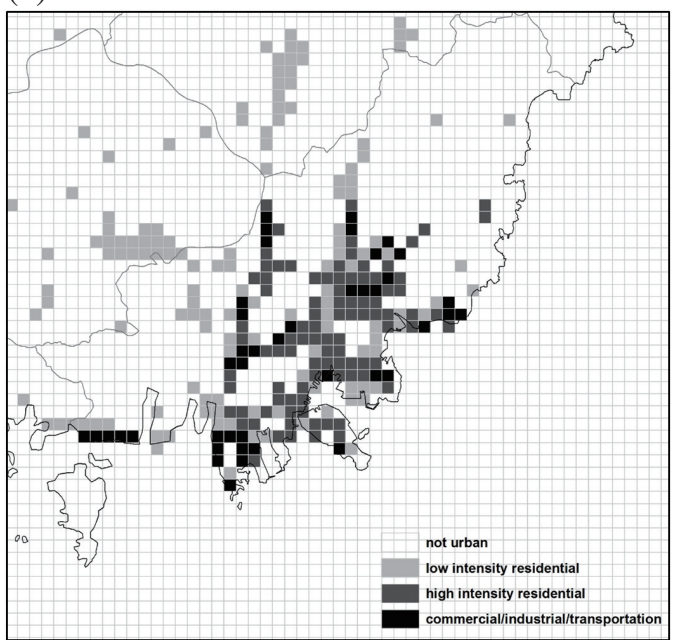

Fig. 3. Distribution of (a) the dominant land use and (b) three urban categories (low and high intensity residential, commercial/industrial/transportation) in Busan and its surroundings. (Color online only) 
(a) $\mathbf{2} \mathbf{~ m}$ air temperature $\left({ }^{\circ} \mathrm{C}\right)$
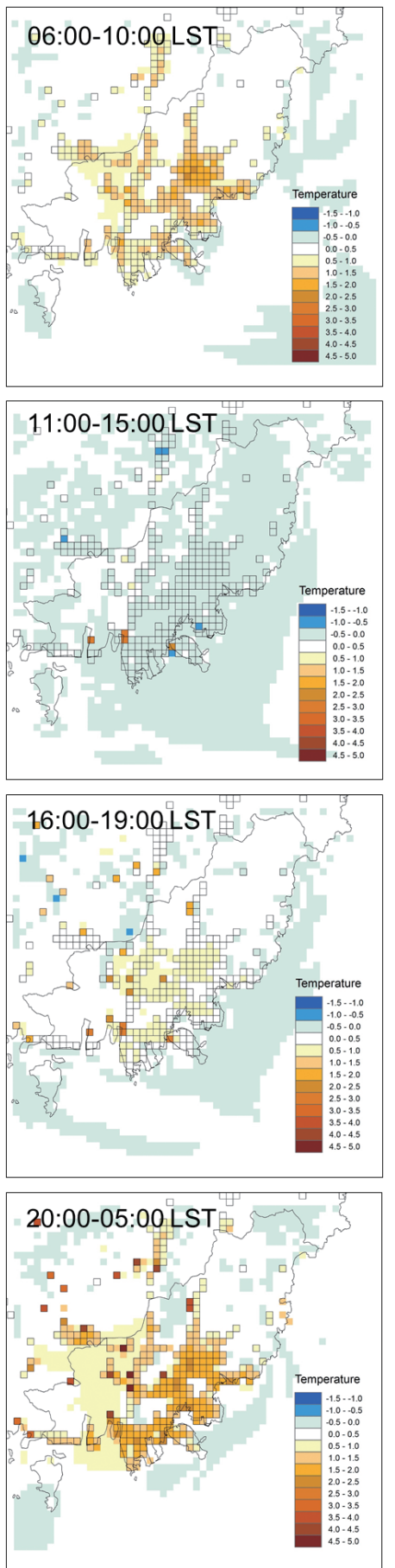

(b) PBL height (m)
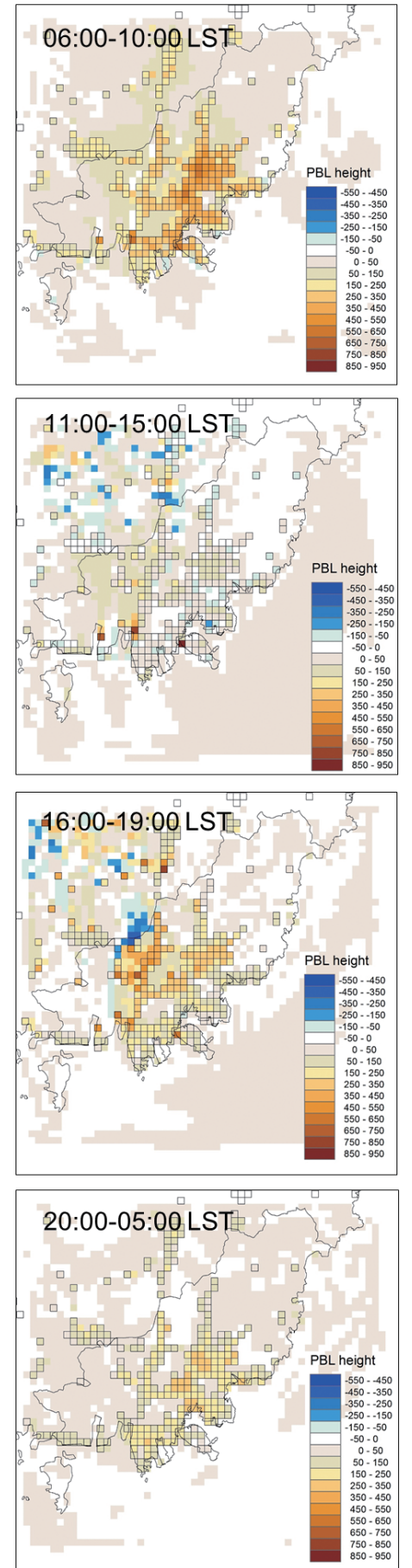

(c) $10 \mathrm{~m}$ wind speed $\left(\mathrm{m} \mathrm{s}^{-1}\right)$
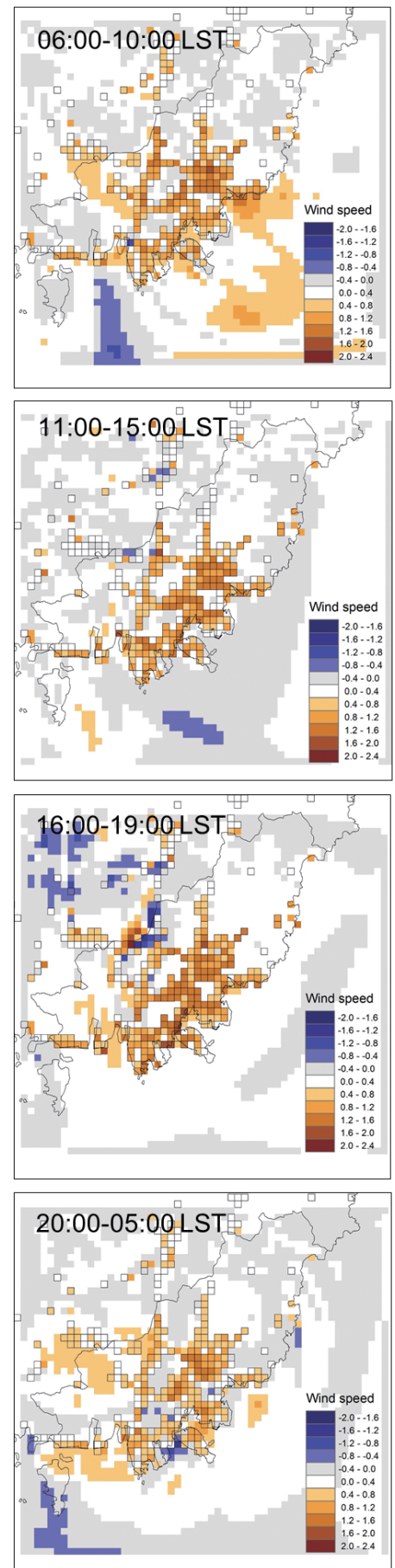

Fig. 4. Spatial distributions of the differences between UCM and NOUCM cases (UCM - NOUCM) for (a) $2 \mathrm{~m}$ temperature, (b) PBL height, and (c) $10 \mathrm{~m}$ wind speed during the four periods (06:00 - 10:00, 11:00 - 15:00, 16:00 - 19:00, and 20:00 - 05:00 LST) on 7 and 8 August 2006. (Color online only)

speeds in the UCM case were on average higher than those in the NOUCM case. The PBL height spatial average for the UCM case was compared with those for the NOUCM case in all areas except for the ocean. The maximum and minimum increases in the UCM case were found to be $77.0 \mathrm{~m}$ in the early morning (06:00 - 10:00 LST) and $5.7 \mathrm{~m}$ around noon (11:00 - 15:00 LST), respectively. These increases in the UCM case were attributable mainly to a rise in surface temperature along the center of this city (Fig. 4a), which in turn enhanced turbulent mixing. Additionally, the sea breeze development, which is generated by horizontal temperature gradients between the land and sea, started earlier and was 
stronger due to the warmer surface temperatures in the urban center. Owing to this process, the wind speed over the land in the UCM case increased on average by $0.2 \mathrm{~m} \mathrm{~s}^{-1}$, but reached up to $2.1 \mathrm{~m} \mathrm{~s}^{-1}$ greater than in the NOUCM case (Fig. 4c). Similar to the surface temperature, the differences in both PBL height and wind speed between the UCM and the NOUCM cases were greater in the urban grid cells than in the non-urban grid cells. In the urban grid cells, deeper PBL heights were predicted, by factors of 8.3 (06:00 - 10:00 LST) to 29.4 (20:00 - 05:00 LST), compared with the nonurban grid cells. The wind speed also shows large differences between the urban and non-urban areas, by factors of 9.8 (20:00 - 06:00 LST) to 16.4 (16:00 - 19:00 LST). In contrast, negative differences in PBL height and wind speed were produced as a result of the decrease in the UCM case in the outskirts of the city during the afternoon. In particular, the PBL height and wind speed spatial distributions during the late afternoon (16:00 - 19:00 LST) showed strong decreases and increases around the northeastern administrative boundary of Busan, due to changes in the wind convergence zone location. The changes in suburban regions, which were not directly affected by the UCM model, are related to the local winds, namely the land-sea circulation, in this domain.

Figure 5 indicates the horizontal wind distributions, including the wind vectors and the wind convergence zone, indicated by the thick black line, at 10:00, 15:00, and 19:00 LST on 7 August 2006, and compares the dominant local flows between the UCM case and the NOUCM case. At 10:00 LST, both the UCM and NOUCM case indicated that the sea breeze, shown as southeasterly and southerly winds, began to develop along the shoreline and penetrated into the center of Busan. The wind convergence zone in the urban center was formed by the interaction between this sea breeze and the light offshore winds of less than $2 \mathrm{~m} \mathrm{~s}^{-1}$. The (a)
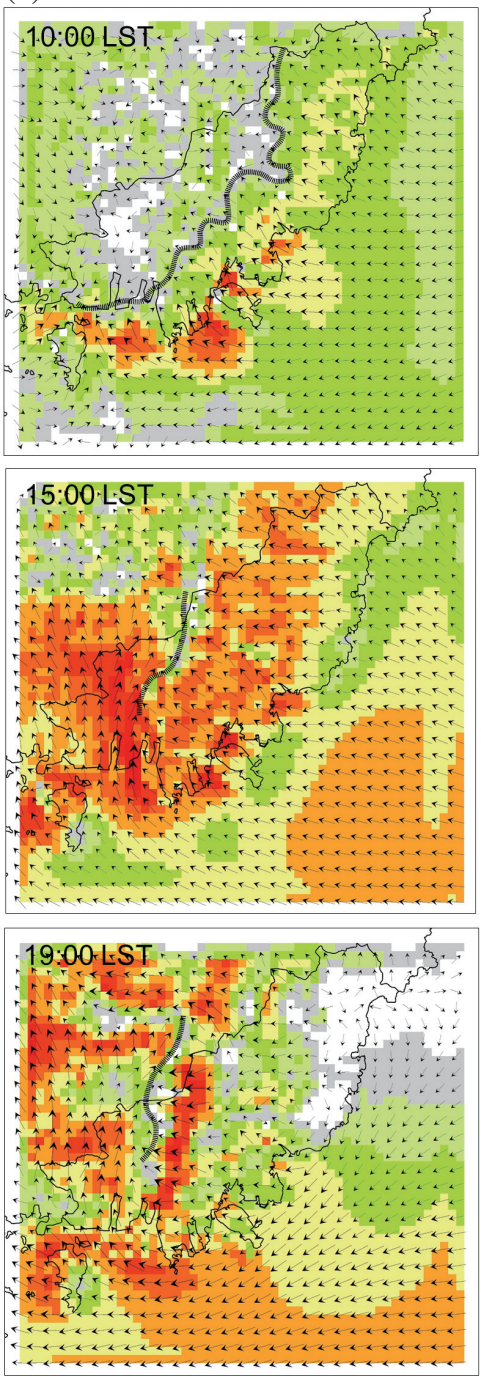

(b) UCM
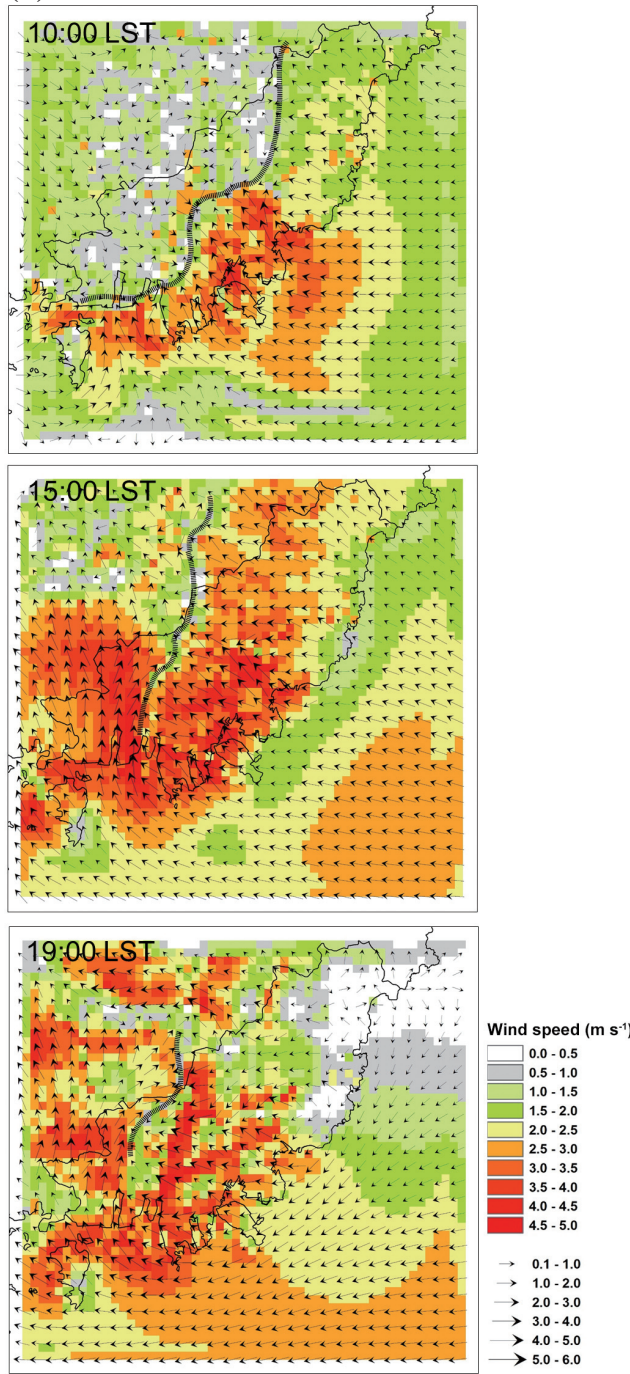

Fig. 5. Spatial distributions of surface winds for the (a) NOUCM case and (b) UCM case at 10:00, 15:00, and 19:00 LST on 7 August 2006. The shaded colors and thick black line indicate wind speeds $\left(\mathrm{m} \mathrm{s}^{-1}\right)$ and the wind convergence zone, respectively. (Color online only) 
valley winds began simultaneously over the inland suburban regions due to the complex topography characterized by various slopes and mountains (see Fig. 1b). However, when compared with the NOUCM case, the sea breeze and offshore winds over Busan were approximately 1.5 - 2.5 and $0.5-2.0 \mathrm{~m} \mathrm{~s}^{-1}$ stronger, respectively, in the UCM case linked to the warmer surface temperatures in the urban center. After 5 hours (15:00 LST), the sea breeze in the NOUCM case extended to the inland northwestern regions of Busan, and thereby combined with the valley winds over the suburban areas. In contrast, the valley winds still remained in the northwestern region at 15:00 LST in the UCM case although the UCM case had stronger southeasterly winds associated with the sea breeze than the NOUCM case. This difference between the UCM case and the NOUCM case could be explained by the weaker sea breeze penetration. These simulation results are in agreement with the findings of Freitas et al. (2007), who reported that the UHI accelerates the sea breeze toward the center of São Paolo. At 19:00 LST, both the UCM and NOUCM cases showed the sea breeze progression into the suburban regions, despite the presence of strong winds inside the city in the UCM case.

\subsection{Difference Between UCM and NOUCM in Terms of Surface $\mathrm{O}_{3}$ Concentrations}

Meteorological changes not only directly influence the simulated $\mathrm{O}_{3}$ concentrations but also affect emission processing at the biogenic and point sources, another input for the $\mathrm{O}_{3}$ simulations (Cheng et al. 2008). However, the emission changes produced by UCM implementation were small in this study because the biogenic and point sources are concentrated in the suburban and rural regions where no appreciable meteorological changes occur. This study is concerned primarily with the meteorological changes impact on $\mathrm{O}_{3}$ simulations when applying the UCM without regard for emission changes.

Figure 6 and Table 2 indicate the simulated and observed $\mathrm{O}_{3}$ concentration spatial distributions at 10:00, 15:00, 19:00, and 05:00 LST for the UCM and NOUCM cases. The summary for changes in $\mathrm{O}_{3}$ concentrations with meteorological variables between the two simulations, respectively, during the same periods are shown in Fig. 4 (06:00 - 10:00, 11:00 - 15:00, 16:00 - 19:00, and 20:00 - 05:00 LST). The results for both $\mathrm{O}_{3}$ simulations are in good agreement with the observations, except for at 19:00 LST. The relatively low $\mathrm{O}_{3}$ concentrations in the downtown area over the entire day were caused by $\mathrm{O}_{3}$ titrations with significant $\mathrm{NO}_{x}$ emissions from mobile sources under a $\mathrm{NO}_{\mathrm{x}}$-saturated environment, in both the simulated and observed cases (Sillman 1999; Jo and Park 2005). The mean $\mathrm{O}_{3}$ differences between the UCM case and the NOUCM case showed positive values over the land area, with the exception of the 11:00 - 15:00 LST period. The $\mathrm{O}_{3}$ concentrations in the UCM case increased by an average of $1.53 \pm 2.10,0.35 \pm 2.94$, and $3.16 \pm 4.64 \mathrm{ppb}$ during 06:00 - 10:00, 16:00 - 19:00, and 20:00 - 05:00 LST, respectively.

In the morning (06:00 - 10:00 LST), the $\mathrm{O}_{3}$ concentrations in the UCM case rose significantly by 10.66 and $8.18 \mathrm{ppb}$ over the urban grids, shown by the black line grid cells, and the southeast coast of the city, respectively. The former increases are linked to the increase in surface temperature and PBL heights in these areas (see Fig. 4a). The high $\mathrm{O}_{3}$ concentrations seen over the coastal area were commonly observed due to the high $\mathrm{O}_{3}$ precursor concentrations emitted from ships in the Busan port (Song et al. 2010). The UCM case predicted higher $\mathrm{O}_{3}$ concentrations along the southeast coast compared with the NOUCM case. This may be caused by the recirculation of a polluted air mass loaded with more $\mathrm{O}_{3}$ produced over the urban center during the previous day in the UCM case. In contrast, during the afternoon hours (11:00 - 15:00 LST), $\mathrm{O}_{3}$ concentrations in the UCM case decreased with little to no change $(-0.26 \pm 1.52 \mathrm{ppb})$ compared with those in the NOUCM case during this time.

In the late afternoon (16:00 - 19:00 LST) remarkable increases in $\mathrm{O}_{3}$ concentrations of up to $17.13 \mathrm{ppb}$, over the downwind region near the wind convergence zone (presented in Fig. 5) are seen in the mean $\mathrm{O}_{3}$ differences. This is attributable mainly to the change in the wind convergence zone location linked to sea breeze penetration under the $\mathrm{UCM}$, as mentioned in section 4.1. The $\mathrm{O}_{3}$ concentrations in the downtown region in the UCM case were slightly higher (up to $10.58 \mathrm{ppb}$ ) than those for the NOUCM case, resulting in a positive $\mathrm{O}_{3}$ difference, due to more active photochemical production of $\mathrm{O}_{3}$ under increased temperatures in this area in the UCM case. As a result, these increases in $\mathrm{O}_{3}$ concentrations in the downtown and downwind area lead to a slight improvement in $\mathrm{O}_{3}$ prediction accuracy in the UCM case, although both the UCM and NOUCM simulations failed to reproduce the extreme high $\mathrm{O}_{3}$ events of more than $180 \mathrm{ppb}$. During the nighttime hours (20:00 - 05:00 LST), the $\mathrm{O}_{3}$ concentrations in the UCM case were higher than those in the NOUCM case in most land areas. This may be the effect of relatively lower surface NO concentrations resulting from the greater PBL height in the UCM case, limiting the $\mathrm{O}_{3}$ destruction process in the form of $\mathrm{O}_{3}$ titration during the nighttime.

For a detailed diurnal comparison between the UCM and NOUCM cases, time-series plots of simulated and observed $\mathrm{O}_{3}$ concentrations at three air quality monitoring sites (shown in Fig. 1) during 5 - 9 August 2006 are given in Fig. 7. Two selected urban sites (YS and BG), and a downwind site (DJ) are located in the downtown and wind convergence area downwind of the sea breeze, respectively. Both the YS and BG sites are directly affected by the UCM modeling. The comparison shows that the UCM case was in slightly better agreement with the observations compared with the NOUCM case in the late afternoon and nighttime, 
(a) Average of difference
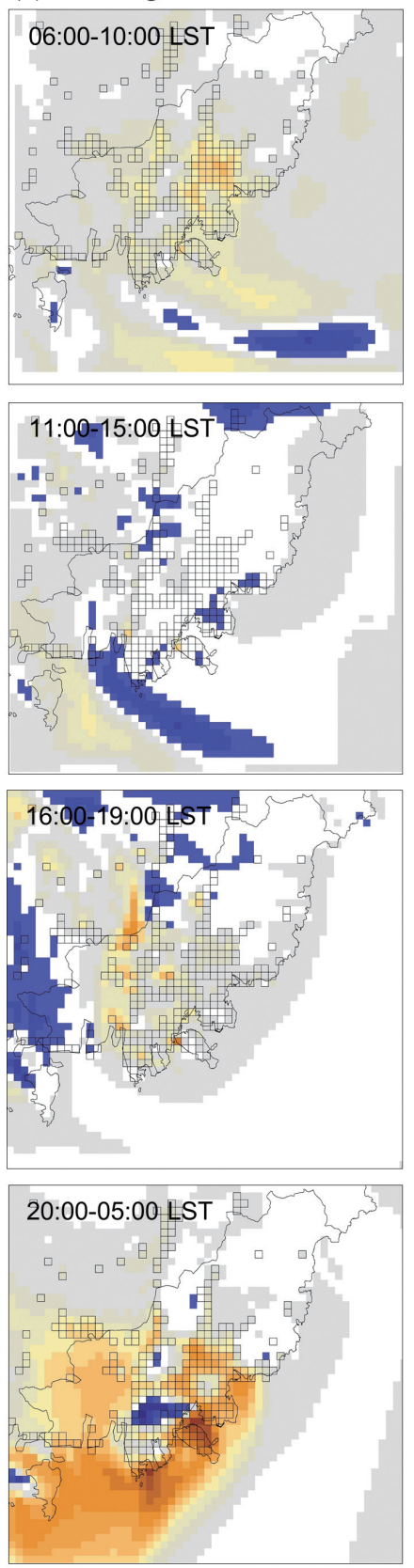

$2,086 \times 202 \times 68,0,2 \times 10,82^{0} 2^{2} 2^{2} 2^{6}(\mathrm{pp})$ (b)

NOUCM
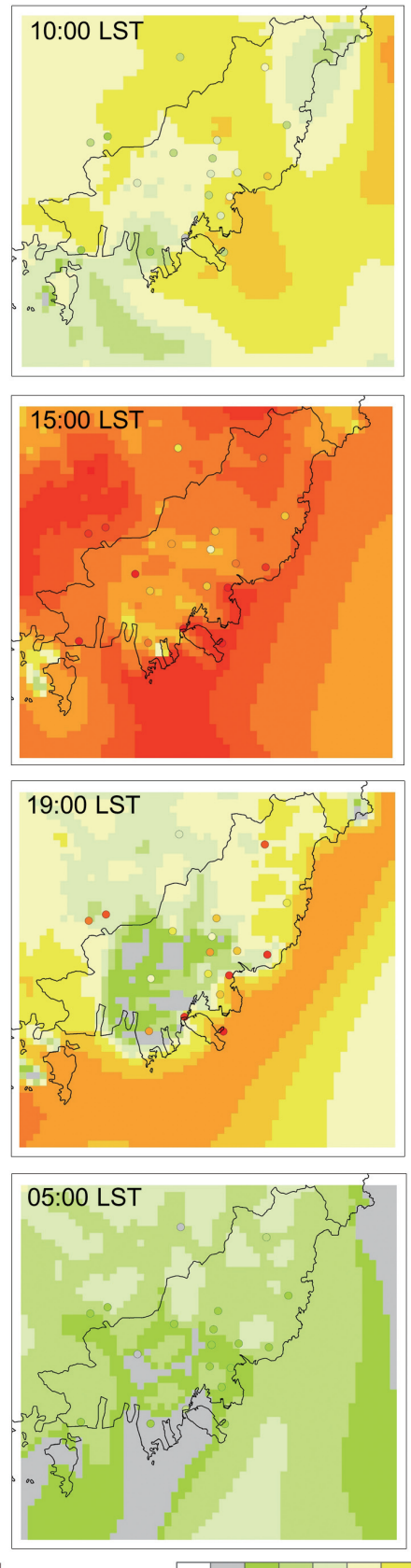

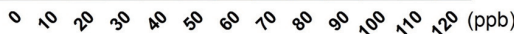

(c) UCM
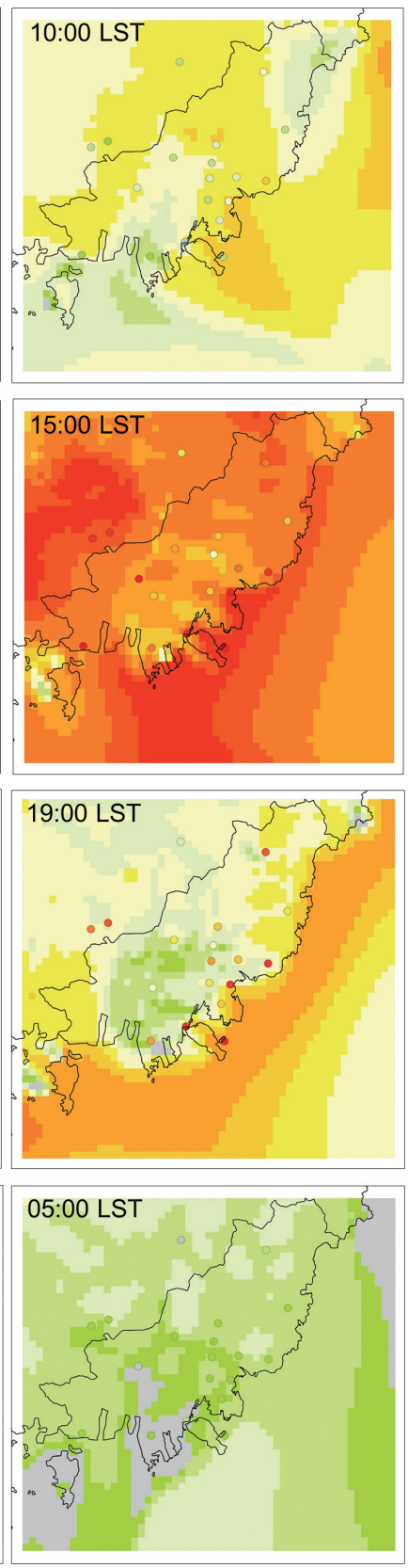

Fig. 6. Spatial distributions of (a) $\mathrm{O}_{3}$ difference between the UCM and NOUCM cases (UCM - NOUCM) during the four periods (06:00 - 10:00, 11:00 - 15:00, 16:00 - 19:00, and 20:00 - 05:00 LST), and simulated $\mathrm{O}_{3}$ for (b) the NOUCM case and (c) the UCM case at 10:00, 15:00, 19:00 LST on 7 August and 05:00 LST on 8 August 2006. Colored dots in (b) and (c) indicate observed $\mathrm{O}_{3}$ concentrations. (Color online only)

Table 2. Summary for changes on meteorological variables $(2 \mathrm{~m}$ temperature, PBL heights, and $10 \mathrm{~m}$ wind speed) and $\mathrm{O}_{3}$ concentrations between the NOUCM and the UCM cases during the four periods (06:00 10:00, 11:00 - 15:00, 16:00 - 19:00, and 20:00 - 05:00 LST) on 7 and 8 August 2006.

\begin{tabular}{ccccc}
\hline Variables & 06:00 - 10:00 LST & 11:00 - 15:00 LST & 16:00 - 19:00 LST & 20:00 - 05:00 LST \\
\hline 2m temperature $\left({ }^{\circ} \mathrm{C}\right)$ & $0.32 \pm 0.42$ & $-0.03 \pm 0.19$ & $0.18 \pm 0.31$ & $0.46 \pm 0.69$ \\
PBL heights $(\mathrm{m})$ & $76.99 \pm 114.57$ & $5.73 \pm 70.33$ & $45.00 \pm 117.88$ & $30.63 \pm 66.44$ \\
$10 \mathrm{~m}$ wind speed $\left(\mathrm{m} \mathrm{s}^{-1}\right)$ & $0.15 \pm 0.31$ & $0.16 \pm 0.37$ & $0.18 \pm 0.46$ & $0.15 \pm 0.31$ \\
$\mathrm{O}_{3}(\mathrm{ppb})$ & $1.53 \pm 2.10$ & $-0.26 \pm 1.52$ & $0.35 \pm 2.94$ & $3.16 \pm 4.64$ \\
\hline
\end{tabular}



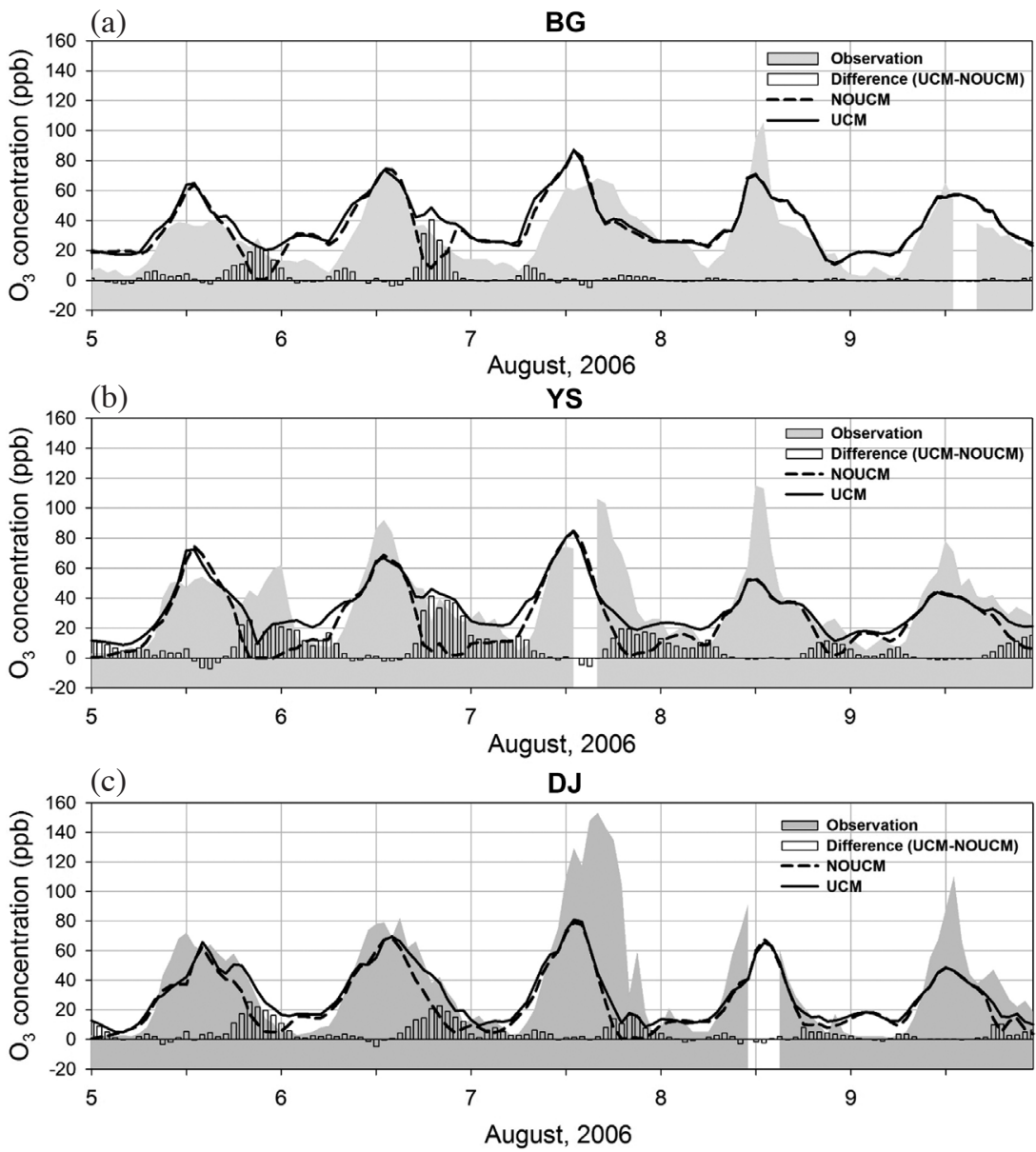

Fig. 7. Time-series plots of $\mathrm{O}_{3}$ concentrations simulated from the UCM and NOUCM cases, and observed $\mathrm{O}_{3}$ concentrations at (a) BG, (b) YS, and (c) DJ during 5 - 9 August 2006.

despite both simulations failing to predict the peak $\mathrm{O}_{3}$ concentrations on 7 and 8 August 2006. In particular, the observed $\mathrm{O}_{3}$ concentrations in the two urban sites (YS and $\mathrm{BG}$ ) remained at 30 - $40 \mathrm{ppb}$ despite a decrease in air temperature and solar radiation in the late afternoon. In the UCM case, these phenomena were well depicted as a result of the added anthropogenic heat in the urban area under the UCM. In contrast, the $\mathrm{O}_{3}$ concentrations in the NOUCM case decreased dramatically after the daily maximum temperature was recorded between 14:00 - 15:00 LST. These trends are also seen at the DJ site, although the differences in $\mathrm{O}_{3}$ concentrations between the UCM and NOUCM cases are smaller than those in the urban sites.

Table 3 indicates the relative changes in $\mathrm{O}_{3}$ concentrations calculated from IPR analysis at the surface level for the three types of air quality monitoring sites in Busan: urban coastal area (UCA), urban downtown area (UDT), and suburban area (SUB) during the four time periods on $7 \mathrm{Au}-$ gust 2006. It should be noted that the main IPR processes are: horizontal transport (HTRA; the sum of horizontal advection and diffusion), vertical transport (VTRA; the sum of vertical advection and diffusion), dry deposition (DEPO), and gas-phase chemical production/destruction (CHEM), which can all lead to changes in the $\mathrm{O}_{3}$ concentrations. On 7 August, $\mathrm{O}_{3}$ chemical loss under both the UCM and NOUCM cases is greater than production during the entire day; due to $\mathrm{O}_{3}+\mathrm{NO}$ titration by high $\mathrm{NO}_{\mathrm{x}}$ emissions in the surface layer (Song et al. 2010). At the UCA and UDT sites $\mathrm{O}_{3}$ chemical loss was reduced in the UCM case during the late afternoon compared with the NOUCM case (16:00 - 19:00 LST). This may be an effect of the increases in PBL height and temperature. In effect higher temperatures under the UCM case induced greater $\mathrm{O}_{3}$ chemical production, while a higher PBL with intense vertical mixing led to a dilution of ambient NO concentrations, resulting in lower $\mathrm{O}_{3}$ titration. The HTRA in the UCM case tended to increase at the coastal and downtown sites. In particular, a significant increase in HTRA under the UCM case at UDT is attributable to the transport of high $\mathrm{O}_{3}$ concentrations and its precursors (e.g., $\mathrm{NO}_{\mathrm{x}}, \mathrm{VOCs}$ ) emitted from coastal industrial facilities and Busan port by a stronger sea breeze during the daytime. In the late afternoon HTRA is reduced in the UCM case due to the prevention of sea breeze penetration inland. In this case, the VTRA is increased under the UCM case. 


\subsection{Statistical Evaluation for the UCM and NOUCM Simulations}

Table 4 provides the RMSE, MBE, and MAE of the meteorological variables of $2 \mathrm{~m}$ temperature and $10 \mathrm{~m}$ wind speed, and the $\mathrm{O}_{3}$ concentrations within the first vertical layer for the UCM and NOUCM cases for the entire simulation period excluding the spin-up time (the first $48 \mathrm{~h}$ ). A comparison of the UCM and NOUCM cases over the entire period indicated that the UCM case was slightly better than the NOUCM case for the $2 \mathrm{~m}$ temperature and $\mathrm{O}_{3}$ concentrations, but slightly worse for the $10 \mathrm{~m}$ wind speeds. The NOUCM case showed a tendency toward a weak cold bias $\left(\mathrm{MBE}<0.0^{\circ} \mathrm{C}\right.$ ) during all periods, whereas the UCM case showed a reduced cold bias due to the addition of anthropogenic heats and urban thermal effects by the UCM. In contrast, the $10 \mathrm{~m}$ wind speeds from both simulations tend to over-predict compared with measurements and the UCM

Table 3. Comparison of the integrated processes rate (IPR) of $\mathrm{O}_{3}$ between the UCM and NOUCM case during the four periods (06:00 - 10:00, 11:00 - 15:00, 16:00 - 19:00, and 20:00 - 05:00 LST) on 7 and 8 August 2006. (a) Urban coastal sites (UCA); (b) Urban downtown sites (UDT); (c) Suburban sites (SUB).

\begin{tabular}{|c|c|c|c|c|c|c|c|c|c|c|c|c|}
\hline \multirow{2}{*}{ (a) } & \multicolumn{3}{|c|}{ 06:00 - 10:00 LST } & \multicolumn{3}{|c|}{ 11:00 - 15:00 LST } & \multicolumn{3}{|c|}{ 16:00 - 19:00 LST } & \multicolumn{3}{|c|}{ 20:00 - 05:00 LST } \\
\hline & NOUCM & UCM & (DIFF) & NOUCM & UCM & (DIFF) & NOUCM & UCM & (DIFF) & NOUCM & UCM & (DIFF) \\
\hline CHEM & -33.4 & -39.9 & $(-6.5)$ & -81.8 & -81.9 & $(-0.2)$ & -150.2 & -140.2 & $(10.1)$ & -48.3 & -59.6 & $(-11.3)$ \\
\hline HTRA & 24.5 & 32.4 & (7.9) & 0.0 & 6.8 & (6.8) & 59.0 & 88.9 & (29.9) & 37.7 & 50.8 & $(13.0)$ \\
\hline VTRA & 20.8 & 35.8 & $(15.1)$ & 172.9 & 178.9 & $(6.0)$ & 143.7 & 119.0 & $(-24.7)$ & 20.8 & 31.5 & $(10.6)$ \\
\hline DEPO & -6.2 & -12.4 & $(-6.2)$ & -21.9 & -37.3 & $(-15.4)$ & -16.4 & -27.0 & $(-10.6)$ & -1.7 & -3.2 & $(-1.5)$ \\
\hline \multirow{2}{*}{ (b) } & \multicolumn{3}{|c|}{ 06:00 - 10:00 LST } & \multicolumn{3}{|c|}{ 11:00 - 15:00 LST } & \multicolumn{3}{|c|}{ 16:00 - 19:00 LST } & \multicolumn{3}{|c|}{ 20:00 - 05:00 LST } \\
\hline & NOUCM & UCM & (DIFF) & NOUCM & UCM & (DIFF) & NOUCM & UCM & (DIFF) & NOUCM & UCM & (DIFF) \\
\hline CHEM & -24.4 & -25.4 & $(-0.9)$ & -40.3 & -40.5 & $(-0.3)$ & -82.1 & -73.8 & $(8.2)$ & -38.9 & -34.4 & (4.6) \\
\hline HTRA & 71.2 & 119.4 & $(48.2)$ & 111.2 & 175.8 & $(64.6)$ & 107.6 & 64.0 & $(-43.6)$ & -1.6 & 19.5 & $(21.1)$ \\
\hline VTRA & -41.4 & -86.7 & $(-45.3)$ & 147.9 & 111.0 & $(-36.9)$ & 220.7 & 307.1 & $(86.5)$ & 69.1 & 53.0 & $(-16.1)$ \\
\hline DEPO & -10.0 & -16.7 & $(-6.7)$ & -34.1 & -45.5 & $(-11.4)$ & -26.8 & -33.1 & $(-6.3)$ & -2.9 & -4.6 & $(-1.6)$ \\
\hline \multirow{2}{*}{ (c) } & \multicolumn{3}{|c|}{ 06:00 - 10:00 LST } & \multicolumn{3}{|c|}{ 11:00 - 15:00 LST } & \multicolumn{3}{|c|}{ 16:00 - 19:00 LST } & \multicolumn{3}{|c|}{ 20:00 - 05:00 LST } \\
\hline & NOUCM & UCM & (DIFF) & NOUCM & UCM & (DIFF) & NOUCM & UCM & (DIFF) & NOUCM & UCM & (DIFF) \\
\hline CHEM & -21.1 & -23.4 & $(-2.3)$ & -45.9 & -46.6 & $(-0.8)$ & -84.6 & -83.4 & (1.1) & -26.0 & -32.9 & $(-6.9)$ \\
\hline HTRA & 51.7 & 52.8 & $(-1.1)$ & -97.6 & -115.6 & $(-17.9)$ & -82.7 & -96.8 & $(-14.1)$ & 19.0 & 20.7 & (1.7) \\
\hline VTRA & -38.5 & -34.8 & (3.7) & 98.4 & 131.1 & $(32.7)$ & 164.6 & 172.4 & (7.8) & 2.6 & 7.2 & $(4.5)$ \\
\hline DEPO & -6.0 & -9.9 & $(-4.0)$ & -19.0 & -29.2 & $(-10.3)$ & -19.4 & -25.9 & $(-6.5)$ & -1.0 & -2.2 & $(-1.2)$ \\
\hline
\end{tabular}

Table 4. Statistical evaluation of observed and predicted meteorological variables ( $2 \mathrm{~m}$ temperature and $10 \mathrm{~m}$ wind speed) and $\mathrm{O}_{3}$ concentrations within the first vertical layer for the NOUCM and UCM cases at several monitoring sites (14 meteorological monitoring sites and 20 air quality monitoring sites) during the entire simulation period.

\begin{tabular}{|c|c|c|c|c|c|c|c|c|c|c|c|}
\hline \multirow{2}{*}{ Variables } & \multirow{2}{*}{ Statistics } & \multicolumn{2}{|c|}{ 06:00 - 10:00 LST } & \multicolumn{2}{|c|}{ 11:00 - 15:00 LST } & \multicolumn{2}{|c|}{ 16:00 - 19:00 LST } & \multicolumn{2}{|c|}{ 20:00 - 05:00 LST } & \multicolumn{2}{|c|}{ Entire period } \\
\hline & & NOUCM & UCM & NOUCM & UCM & NOUCM & UCM & NOUCM & UCM & NOUCM & UCM \\
\hline \multirow{3}{*}{$\begin{array}{c}2 \mathrm{~m} \text { temperature } \\
\left({ }^{\circ} \mathrm{C}\right)\end{array}$} & $\mathrm{RMSE}^{\mathrm{a}}$ & +1.66 & +1.91 & +1.73 & +1.77 & +2.02 & +1.96 & +1.52 & +1.85 & +2.67 & +1.95 \\
\hline & $\mathrm{MBE}^{\mathrm{b}}$ & -0.15 & +0.62 & -1.29 & -1.32 & -1.46 & -1.14 & -0.68 & +0.24 & -0.83 & -0.24 \\
\hline & $\mathrm{MAE}^{\mathrm{c}}$ & +1.36 & +1.63 & +1.53 & +1.57 & +1.80 & +1.74 & +1.35 & +1.66 & +1.47 & +1.65 \\
\hline \multirow{3}{*}{$\begin{array}{c}10 \mathrm{~m} \text { wind speed } \\
\left(\mathrm{m} \mathrm{s}^{-1}\right)\end{array}$} & RMSE & +0.91 & +1.37 & +1.05 & +1.32 & +1.10 & +1.52 & +1.12 & +1.60 & +1.08 & +1.48 \\
\hline & MBE & +0.17 & +0.92 & -0.11 & +0.61 & +0.91 & +0.80 & +0.39 & +1.09 & +0.14 & +0.86 \\
\hline & MAE & +0.71 & +1.13 & +0.87 & +1.13 & 0.00 & +1.28 & +0.89 & +1.31 & +0.85 & +1.21 \\
\hline \multirow{3}{*}{$\begin{array}{c}\mathrm{O}_{3} \text { concentration } \\
(\mathrm{ppb})\end{array}$} & RMSE & +13.2 & +15.2 & +24.9 & +24.8 & +31.5 & +30.0 & +20.4 & +16.5 & +22.4 & +20.9 \\
\hline & MBE & +8.1 & +11.0 & +2.9 & +2.4 & -1.5 & -0.3 & -4.7 & +1.5 & -0.1 & +3.4 \\
\hline & MAE & +10.8 & +13.0 & +18.9 & +18.8 & +22.9 & +21.5 & +15.2 & +12.3 & +16.3 & +15.3 \\
\hline
\end{tabular}

Note: a: RMSE: root mean square error; $b$ : MBE: mean bias error; $c$ : MAE: mean absolute error. 
case has larger errors than the NOUCM case over the entire period owing to the sea breeze reinforcement. For the $\mathrm{O}_{3}$ concentrations, the UCM case has smaller bias errors (MAE and MBE) and RMSE than the NOUCM case over the entire period, with the exception of during 06:00 - 10:00 LST.

Figure 8 presents the temporal variation in MBE values for surface temperature, wind speed, and $\mathrm{O}_{3}$ concentrations for the UCM and NOUCM cases. Compared with the NOUCM case, the UCM case temperature showed warm bias of up to $2.3^{\circ} \mathrm{C}$ during most of the simulation periods, especially in the late afternoon and nighttime (Fig. 8a). At the same time, the ability of the UCM case to simulate $\mathrm{O}_{3}$ concentrations was significantly improved in the late afternoon and nighttime, with smaller MBE values than the NOUCM case (see Fig. 8c). This improvement in $\mathrm{O}_{3}$ prediction of the UCM case during the late afternoon is attributable to more $\mathrm{O}_{3}$ production with regard to the increase in surface temperature and PBL heights under the under-predicted $\mathrm{O}_{3}$ conditions. As a result, UCM application led to a slight improvement in the $\mathrm{O}_{3}$ simulation in the late afternoon and nighttime despite both the improvement and deterioration of the meteorological simulation results.

\section{CONCLUSION}

The impact of the UCM with detailed urban land-use and urban heats on meteorology and surface $\mathrm{O}_{3}$ concentrations in the coastal urban area of Busan were evaluated in this study using the WRF-SMOKE-CMAQ model. The differences between simulations with and without the UCM, termed the UCM case and the NOUCM case, respectively, showed the changes in local meteorological factors as well as surface $\mathrm{O}_{3}$ concentrations caused by UCM implementation.

The UCM case surface temperatures are generally warmer than in the NOUCM case, especially during the early morning (06:00 - 10:00 LST) and nighttime (20:00 - 05:00 LST) on the episodic days. This urban heating effect from the UCM results in greater PBL heights of up to $77.0 \mathrm{~m}$ in the early morning, due to turbulent mixing enhancement in the urban area. This modifies the local circulations within the Busan metropolitan area. In the UCM case the sea breeze and offshore winds, which are the prevailing flows in the study area, are stronger due to the stronger convergence caused by higher temperatures in the city center. The UHI effects induce faster and stronger sea breeze penetration, but after sea breeze arrival at the urban center, its penetration further inland is limited.

These changes in meteorological conditions lead to slight changes in the $\mathrm{O}_{3}$ distribution across the study area. The surface $\mathrm{O}_{3}$ concentrations predicted by the UCM case, compared with the NOUCM case, increase by on average $1.53,0.35$, and $3.2 \mathrm{ppb}$ for the 06:00 - 10:00, 16:00 - 19:00,
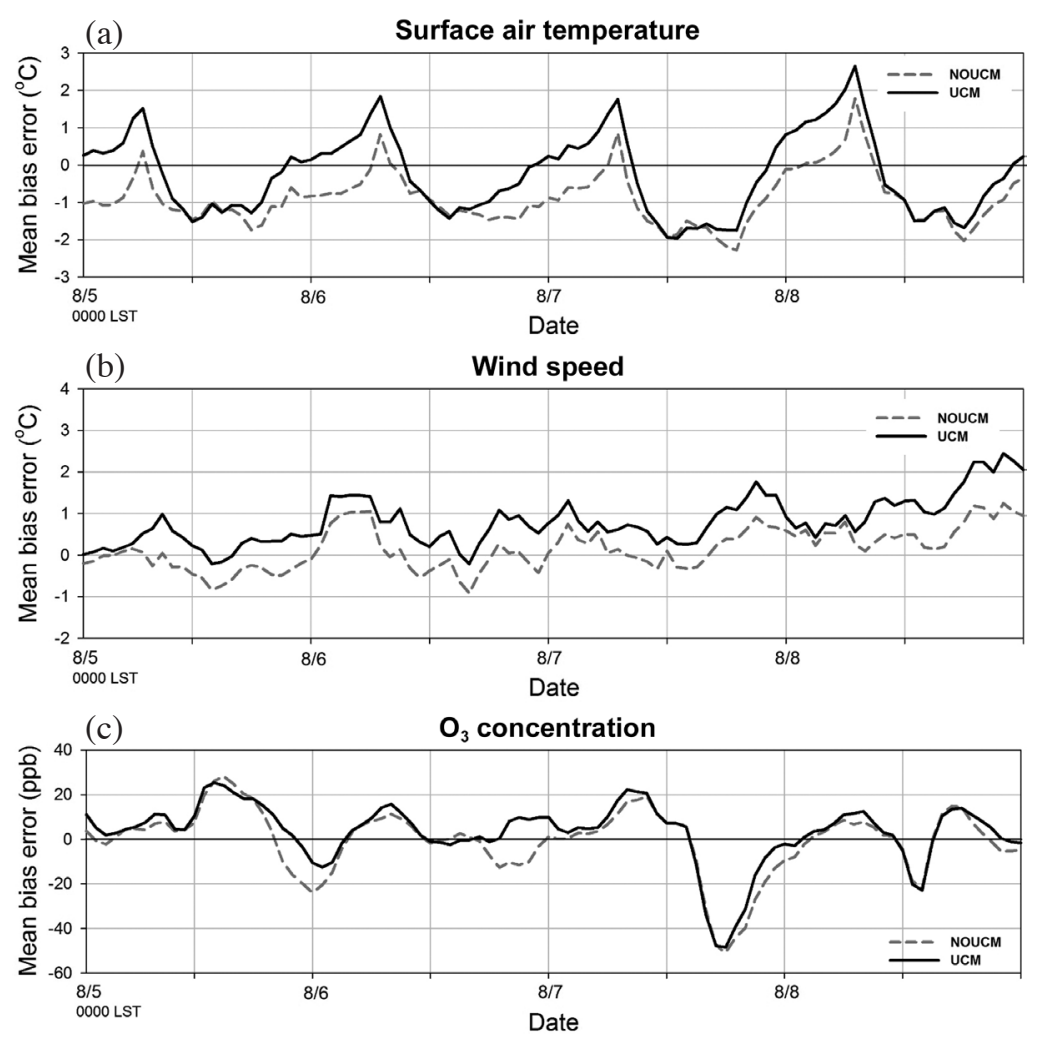

Fig. 8. Time-series plots of mean bias error in the NOUCM and UCM cases for (a) surface air temperature, (b) wind speed at the meteorological monitoring sites, and (c) $\mathrm{O}_{3}$ concentrations at the air quality monitoring sites in the study domain during 6 - 8 August 2006. 
and 20:00 - 05:00 LST, respectively. However, in the late afternoon (16:00 - 19:00 LST), remarkable increases in $\mathrm{O}_{3}$ concentrations over the downwind (up to $17.1 \mathrm{ppb}$ ) and downtown areas (up to $10.6 \mathrm{ppb}$ ) are simulated in the UCM case. These are likely due to an increase in temperature and PBL heights in the urban areas and wind convergence zone movement with respect to the changing sea breeze and offshore flow interaction. The increase in $\mathrm{O}_{3}$ concentrations in the late afternoon contributes to reducing the CMAQ model bias for underestimating $\mathrm{O}_{3}$ conditions. The simulated $\mathrm{O}_{3}$ concentrations in the UCM case are more similar to the observed $\mathrm{O}_{3}$ concentrations than those of the NOUCM.

This study demonstrates that a UCM can represent the detailed urban canopy and urban heat effects, and also has the potential to more accurately simulate meteorological factors and air pollutants. In order to reproduce accurate local meteorological conditions and air quality in an urban area, development and improvement of urban surface parameterizations within the UCM is needed based on specific urban morphology derived from high-resolution GIS data.

Acknowledgements This work was funded by the Korea Meteorological Administration Research and Development Program under Grant KMIPA 2015-2050. This work was also funded by the Korea Meteorological Administration Research and Development Program under Grant CATER_2012-6140.

\section{REFERENCES}

Ado, H. Y., 1992: Numerical study of the daytime urban effect and its interaction with the sea breeze. J. Appl. Meteorol., 31, 1146-1164, doi: 10.1175/1520-0450(1992)031<1146:NSOTDU>2.0.CO;2. [Link]

Advanced Research WRF, 2009: Weather Research and Forecasting, Version 3 Modeling System User's Guide.

Byun, D. W. and J. K. S. Ching, 1999: Science algorithms of the EPA Models-3 community multiscale air quality (CMAQ) modeling system. Report EPA/600/R-99/030, U.S. Environmental Protection Agency, Washington, DC.

Chen,F. and J.Dudhia, 2001: Coupling an advanced land surface-hydrology model with the Penn State-NCAR MM5 modeling system. Part II: Preliminary model validation. Mon. Weather Rev., 129, 587-604, doi: 10.1175/15200493(2001)129<0587:CAALSH>2.0.CO;2. [Link]

Chen, F., H. Kusaka, R. Bornstein, J. Ching, C. S. B. Grimmond, S. Grossman-Clarke, T. Loridan, K. W. Manning, A. Martilli, S. Miao, D. Sailor, F. P. Salamanca, H. Taha, M. Tewari, X. Wang, A. A. Wyszogrodzki, and C. Zhang, 2011: The integrated WRF/urban modelling system: Development, evaluation, and applications to urban environmental problems. Int. J. Climatol., 31, 273-288, doi: 10.1002/joc.2158. [Link]
Cheng, F. Y., S. Kim, and D. W. Byun, 2008: Application of high resolution land use and land cover data for atmospheric modeling in the Houston-Galveston Metropolitan area: Part II Air quality simulation results. Atmos. Environ., 42, 4853-4869, doi: 10.1016/j. atmosenv.2008.02.059. [Link]

Dudhia, J., 1989: Numerical study of convection observed during the winter monsoon experiment using a mesoscale two-dimensional model. $J$. Atmos. Sci., 46, 3077-3107, doi: 10.1175/1520-0469(1989)046<3077:NSOCOD>2.0.CO;2 . [Link]

Emery, C., E. Tai, and G. Yarwood, 2001: Enhanced meteorological modeling and performance evaluation for two Texas ozone episodes. Texas Natural Resources Conservation Commission, prepared by ENVIRON, International Corporation, Novato.

Freitas, E. D., C. M. Rozoff, W. R. Cotton, and P. L. S. Dias, 2007: Interactions of an urban heat island and seabreeze circulations during winter over the metropolitan area of São Paulo, Brazil. Bound.-Layer Meteor., 122, 43-65, doi: 10.1007/s10546-006-9091-3. [Link]

Grossman-Clarke, S., J. A. Zehnder, W. L. Stefanov, Y. Liu, and M. A. Zoldak, 2005: Urban modifications in a mesoscale meteorological model and the effects on near-surface variables in an arid metropolitan region. J. Appl. Meteorol., 44, 1281-1297, doi: 10.1175/ jam2286.1. [Link]

Heald, C. L. and D. V. Spracklen, 2015: Land use change impacts on air quality and climate. Chem. Rev., 115, 4476-4496, doi: 10.1021/cr500446g. [Link]

Hong, S. Y. and J. O. J. Lim, 2006: The WRF single-moment 6-class microphysics scheme (WSM6). J. Kor. Meteorol. Soc., 42, 129-151.

Hong, S. Y., Y. Noh, and J. Dudhia, 2006: A new vertical diffusion package with an explicit treatment of entrainment processes. Mon. Weather Rev., 134, 2318-2341, doi: 10.1175/mwr3199.1. [Link]

Jo, W. K. and J. H. Park, 2005: Characteristics of roadside air pollution in Korean metropolitan city (Daegu) over last 5 to 6 years: Temporal variations, standard exceedances, and dependence on meteorological conditions. Chemosphere, 59, 1557-1573, doi: 10.1016/j. chemosphere.2004.12.021. [Link]

Kain, J. S., 2004: The Kain-Fritsch convective parameterization: An update. J. Appl. Meteorol., 43, 170-181, doi: 10.1175/1520-0450(2004)043<0170:TKCPAU> 2.0.CO;2. [Link]

Kang, J.E., S. K. Song, H. W. Lee, and Y. K. Kim, 2012: The influence of meteorological conditions and complex topography on ozone concentrations in a valley area near coastal metropolitan cities. Terr. Atmos. Ocean. Sci., 23, 25-38, doi: 10.3319/tao.2011.06.30.02(A). [Link]

Kim, Y., K. Sartelet, J. C. Raut, and P. Chazette, 2015: Influence of an urban canopy model and PBL schemes on 
vertical mixing for air quality modeling over Greater Paris. Atmos. Environ., 107, 289-306, doi: 10.1016/j. atmosenv.2015.02.011. [Link]

Kusaka, H. and F. Kimura, 2004: Coupling a single-layer urban canopy model with a simple atmospheric model: Impact on urban heat island simulation for an idealized case. J. Meteorol. Soc. Jpn., 82, 67-80, doi: 10.2151/ jmsj.82.67. [Link]

Kusaka, H., H. Kondo, Y. Kikegawa, and F. Kimura, 2001: A simple single-layer urban canopy model for atmospheric models: Comparison with multi-layer and slab models. Bound.-Layer Meteor., 101, 329-358, doi: 10.1023/A:1019207923078. [Link]

Liao, J., T. Wang, Z. Jiang, B. Zhuang, M. Xie, C. Yin, X. Wang, J. Zhu, Y. Fu, and Y. Zhang, 2015: WRF/Chem modeling of the impacts of urban expansion on regional climate and air pollutants in Yangtze River Delta, China. Atmos. Environ., 106, 204-214, doi: 10.1016/j. atmosenv .2015.01.059. [Link]

Liu, C. M., C. Y. Huang, S. L. Shieh, and C. C. Wu, 1994: Important meteorological parameters for ozone episodes experienced in the Taipei basin. Atmos. Environ., 28, 159-173, doi: 10.1016/1352-2310(94)90031-0. [Link]

Mlawer, E. J., S. J. Taubman, P. D. Brown, M. J. Iacono, and S. A. Clough, 1997: Radiative transfer for inhomogeneous atmosphere: RRTM, a validated correlated-k model for the longwave. J. Geophys. Res., 102, 1666316682, doi: 10.1029/97jd00237. [Link]

National Institute of Environmental Research (NIER), 2009: National Air Pollutants Emission 2007. (in Korean)

NRC (National Research Council), 1991: Rethinking the Ozone Problem in Urban and Regional Air Pollution, National Academy Press, 524 pp, doi: 10.17226/1889. [Link]

Oh, I. B., Y. K. Kim, H. W. Lee, and C. H. Kim, 2006: An observational and numerical study of the effects of the late sea breeze on ozone distributions in the Busan metropolitan area, Korea. Atmos. Environ., 40, 12841298, doi: 10.1016/j.atmosenv.2005.10.049. [Link]

Park, H. M. and T. K. Baek, 2009: Progress and land-use characteristics of urban sprawl in Busan metropolitan city using remote sensing and GIS. J. Korean Assoc. Geogr. Inform. Stud., 12, 23-33. (in Korean)

Shi, T., Y. Huang, H. Wang, C. E. Shi, and Y. J. Yang, 2015: Influence of urbanization on the thermal environment of meteorological station: Satellite-observed evidence. Adv. Clim. Change Res., 6, 7-15, doi: 10.1016/j.accre.2015.07.001. [Link]

Sillman, S., 1999: The relation between ozone, $\mathrm{NO}_{x}$ and hydrocarbons in urban and polluted rural environments. Atmos. Environ., 33, 1821-1845, doi: 10.1016/s13522310(98)00345-8. [Link]
Skamarock, W. C., J. B. Klemp, J. Dudhia, D. O. Gill, D. M. Barker, M. G. Duda, X. Y. Huang, W. Wang, and J. G. Powers, 2008: A description of the advanced research WRF version 3. NCAR Technical Note NCAR/ TN-475+STR, National Center for Atmospheric Research, Boulder, Colorado, USA, 125 pp, doi: 10.5065/ D68S4MVH. [Link]

Song, S. K., Z. H. Shon, Y. K. Kim, Y. H. Kang, I. B. Oh, and C. H. Jung, 2010: Influence of ship emissions on ozone concentrations around coastal areas during summer season. Atmos. Environ., 44, 713-723, doi: 10.1016/j.atmosenv.2009.11.010. [Link]

Song, S. K., Z. H. Shon, Y. K. Kim, Y. H. Kang, and K. H. Kim, 2011: An oil spill accident and its impact on ozone levels in the surrounding coastal regions. Atmos. Environ., 45, 1312-1322, doi: 10.1016/j. atmosenv.2010.11.055. [Link]

Tewari, M., F. Chen, H. Kusaka, and S. Miao, 2007: Coupled WRF/Unified Noah/Urban-canopy modeling system. NCAR WRF Documentation, NCAR, Boulder, 22 pp.

Wang, X., W. S. Lin, L. M. Yang, R. R. Deng, and H. Lin, 2007: A numerical study of influences of urban land-use change on ozone distribution over the Pearl River Delta region, China. Tellus, 59B, 633-641, doi: 10.3402/tellusb.v59i3.17043. [Link]

Wang, X., F. Chen, Z. Wu, M. Zhang, M. Tewari, A. Guenther, and C. Wiedinmyer, 2009: Impacts of weather conditions modified by urban expansion on surface ozone: Comparison between the Pearl River Delta and Yangtze River Delta regions. Adv. Atmos. Sci., 26, 962972, doi: 10.1007/s00376-009-8001-2. [Link]

Wang, X., Y. Zhang, Y. Hu, W. Zhou, K. Lu, L. Zhong, L. Zeng, M. Shao, M. Hu, and A. G. Russell, 2010: Process analysis and sensitivity study of regional ozone formation over the Pearl River Delta, China, during the PRIDE-PRD2004 campaign using the Community Multiscale Air Quality modeling system. Atmos. Chem. Phys., 10, 4423-4437, doi: 10.5194/acp-10-4423-2010. [Link]

Yoshikado, H., 1994: Interaction of the sea breeze with urban heat islands of different sizes and locations. J. Meteorol. Soc. Jpn., 72, 139-143.

Yu, M., G. R. Carmichael, T. Zhu, and Y. Cheng, 2012: Sensitivity of predicted pollutant levels to urbanization in China. Atmos. Environ., 60, 544-554, doi: 10.1016/j. atmosenv.2012.06.075. [Link]

Zehnder, J. A., 2002: Simple modifications to improve fifthgeneration Pennsylvania State University-National Center for Atmospheric Research Mesoscale Model performance for the Phoenix, Arizona, metropolitan area. J. Appl. Meteorol., 41, 971-979, doi: 10.1175/15200450(2002)041<0971:SMTIFG>2.0.CO;2. [Link] 